\title{
Uji Aktivitas Antimikroba Ekstrak Kulit Ranting dan Kayu Sakit Sengon (Falcataria moluccana) dengan Pelarut Metanol dan Etil Asetat
}

\author{
Alfi Rumidatul ${ }^{1}$, Bunga Wahyuniah ${ }^{2}$, Deni Zamaludin², Wasiyah Khusna $\mathbf{F}^{2}$, \\ Feldha Fadhila ${ }^{2}$, Yayan Maryana ${ }^{3}$, \\ ${ }^{1}$ Sekolah Ilmu dan Teknologi Hayati, Institut Teknologi Bandung, Indonesia \\ ${ }^{2}$ Jurusan Analis Kesehatan, Institut Kesehatan Rajawali, Indonesia \\ ${ }^{3}$ Jurusan Farmasi, Politeknik Meta Industri, Indonesia
}

\begin{tabular}{l} 
Article Info \\
\hline Article history: \\
Received Sep $04^{\text {th }}, 2020$ \\
Revised Jan $31^{\text {th }}, 2021$ \\
Accepted Jan $31^{\text {th }}, 2021$ \\
\hline
\end{tabular}

Keyword:

Falcataria moluccana, Antimicrobial,

Methanol,

Ethyl acetate,

\begin{abstract}
Sengon (Falcataria moluccana) has various metabolite compounds and has antimicrobial activity both on the skin and leaves. This study aims to determine the potential of Sengon extract as an antimicrobial. The method used in the extraction of the extract was maceration with methanol and ethyl acetate solvents and was made into five concentration variants, namely 9\%, 9.5\%, 10\%, 10.5\%, and $11 \%$, while testing the antimicrobial activity was carried out by the disc diffusion method or Kirby bauer against the test microbes, namely Staphylococcus aureus, Pseudomonas aeruginosa, Proteus mirabilis, Salmonella typhi, Shigella dysenteriae, Klebsiella pneumonia, Escerichia coli, and Candida albicans. The results showed that the optimum concentration of sick twig bark extract with methanol solvent was $11 \%$ in $S$. aureus with a diameter of $8.3 \mathrm{~mm}, P$. mirabilis with a diameter of $4.3 \mathrm{~mm}, P$. aeruginosa with a diameter of $0.5 \mathrm{~mm}$, K. pneumoniae with $9 \mathrm{~mm}$ in diameter, and E. coli with a diameter of $7 \mathrm{~mm}$. The optimum concentration of sick twig bark extract with methanol solvent was also found at a concentration of $10 \%$ and $11 \%$ in S. dysenteriae and C. albicans with a diameter of 3 $\mathrm{mm}$, and in $S$. thypi with a diameter of $6 \mathrm{~mm}$. The optimum concentration of sengon wood extract with methanol solvent was $11 \%$ in $S$. aureus with a diameter of $8.3 \mathrm{~mm}$, P. mirabilis with a diameter of $5.6 \mathrm{~mm}$, and $P$. aeruginosa with a diameter of $9 \mathrm{~mm}$. The optimum concentrations of sengon sore wood extract with ethyl acetate solvent were $10 \%, 10.5 \%$, and $11 \%$ against C. albicans with a diameter of $2 \mathrm{~mm}$. The results showed that the extract of Sengon sore twig bark and wood with methanol and ethyl acetate solvents could inhibit the growth of the tested microbes with different extract optimum concentrations for each test microbe.
\end{abstract}

\begin{abstract}
ABSTRAK
Sengon (Falcataria moluccana) memiliki senyawa metabolit yang beragam dan memiliki aktivitas antimikroba baik pada bagian kulit dan daunnya. Penelitian ini bertujuan untuk mengetahui potensi ekstrak Sengon sebagai antimikroba. Metode yang digunakan dalam pembuatan ekstrak adalah maserasi dengan pelarut metanol dan etil asetat dan dibuat menjadi lima varian konsentrasi yaitu 9\%, 9,5\%, 10\%, 10,5\%, dan $11 \%$ sedangkan untuk pengujian aktivitas antimikroba dilakukan dengan metode difusi cakram atau Kirby bauer terhadap mikroba uji yaitu Staphylococcus aureus, Pseudomonas aeruginosa, Proteus mirabilis, Salmonella typhi, Shigella dysenteriae, Klebsiella pneumonia, Escerichia coli, dan Candida albicans. Hasil penelitian menunjukkan konsentrasi optimum ekstrak kulit ranting sakit dengan pelarut metanol yaitu $11 \%$ pada $S$. aureus dengan diameter $8,3 \mathrm{~mm}, P$. mirabilis dengan diameter $4,3 \mathrm{~mm}, P$. aeruginosa dengan diameter $0,5 \mathrm{~mm}, K$. pneumonia dengan diameter $9 \mathrm{~mm}$, dan E. coli dengan diameter $7 \mathrm{~mm}$. Konsentrasi optimum ekstrak kulit ranting sakit dengan pelarut metanol juga terdapat pada konsentrasi $10 \%$ dan $11 \%$ pada $S$. dysenteriae dan $C$. albicans dengan diameter $3 \mathrm{~mm}$, dan pada $S$. thypi dengan diameter $6 \mathrm{~mm}$. Konsentrasi
\end{abstract}


optimum ekstrak kayu sakit sengon dengan pelarut metanol yaitu $11 \%$ pada $S$. aureus dengan diameter $8,3 \mathrm{~mm}, P$. mirabilis dengan diameter 5,6 $\mathrm{mm}$, dan $P$. aeruginosa dengan diameter $9 \mathrm{~mm}$. Konsentrasi optimum ekstrak kayu sakit sengon dengan pelarut etil asetat yaitu 10\%, 10,5\%, dan $11 \%$ terhadap C. albicans dengan diameter 2 mm. Hasil yang didapat menunjukkan bahwa ekstrak kulit ranting dan kayu Sengon sakit dengan pelarut metanol dan etil asetat dapat menghambat pertumbuhan mikroba uji dengan konsentrasi optimum ekstrak yang berbeda untuk setiap mikroba uji.

Kata Kunci : Falcataria moluccana, Antimikroba, Metanol, Etil asetat

\section{Pendahuluan}

Penyakit infeksi masih menjadi masalah kesehatan yang paling utama. Infeksi merupakan penyakit yang disebabkan oleh masuknya mikroorganisme patogen ke dalam tubuh biasanya disebabkan oleh jamur dan bakteri, baik bakteri Gram positif maupun Gram negatif. Beberapa bakteri yang sering menyebabkan infeksi adalah Staphylococcus aureus, Pseudomonas aeruginosa, Proteus mirabilis, Salmonella typhi, Shigella dysenteriae, Klebsiella pneumonia, dan Escerichia coli, sedangkan untuk jamur salah satunya yaitu Candida albicans yang menjadi penyebab penyakit kandidiasis. Akibat tingginya penyakit infeksi, maka pemberian antibiotik masih menjadi pilihan utama. Antibiotik merupakan kemajuan terapi yang paling signifikan dalam menurunkan angka kesakitan dan kematian. Penatalaksanaan penyakit infeksi dengan antibiotik memunculkan permasalahan baru, yaitu meningkatnya resistensi bakteri terhadap antibiotik yang menyebabkan terapi penyakit infeksi menjadi semakin sulit (Wiryadana et al., 2019).

Berbagai studi menunjukkan bahwa sekitar 40-62\% antibiotik digunakan secara tidak tepat antara lain untuk penyakit-penyakit yang sebenarnya tidak memerlukan antibiotik (Kurniawati \& Mashartini, 2016). Akibat dari banyaknya resistensi yang terjadi maka pemanfaatan bahan alam sebagai antibiotik alternatif menjadi pilihan utama. Salah satu bahan alam yang dapat dimanfaatkan adalah Sengon (Falcataria moluccana). Sengon merupakan tanaman yang banyak manfaatnya, selain kayunya yang dapat dimanfaatkan sebagai bahan baku furniture, daun dan cabang yang jatuh akan meningkatkan kandungan nitrogen, bahan organik dan mineral pada tanah (Krisnawati, H H. et al., 2011).

Ekstrak kulit kayu sengon memiliki potensi sebagai antimikroba. Menurut Fahrizal, (2014) ekstrak kulit kayu Sengon dengan pelarut air, etanol 70\%, dan etanol 96\% memiliki beberapa senyawa metabolit sekunder yaitu tanin, saponin, flavonoid, triterpenoid, dan steroid dimana senyawa steroid ini diketahui memiliki aktivitas kardiotonik dan antibakteri. Penelitian yang telah dilakukan oleh Azizah et al., (2018) dan Pratiwi et al., (2019) adalah memanfaatkan senyawa metabolit di dalam ekstrak bubuk gergaji Sengon sebagai insektisida, sedangkan pemanfaatan senyawa metabolit Sengon untuk antibakteri belum dilakukan.

Setiap tanaman memiliki karakter senyawa metabolit sekunder yang berbeda tingkat kepolarannya, Senyawa polar akan mudah larut pada pelarut yang bersifat polar, sedangkan senyawa nonpolar juga akan mudah larut pada pelarut yang bersifat nonpolar sehingga pemilihan pelarut dalam pembuatan ekstrak sangat penting untuk dilakukan (Pratiwi et al., 2019). Potensi senyawa metabolit sebagai antibakteri dapat dilihat dengan melakukan uji aktivitas antimikroba ekstrak terhadap bakteri penyebab penyakit yang sering dijumpai. Senyawa metabolit pada Sengon sebagai antibakteri dapat dikembangkan sebagai antibiotik alternatif untuk menekan penyakit infeksi agar resistensi bakteri terhadap antibiotik dapat dikendalikan. 
Maka dari itu penelitian ini bertujuan untuk mengetahui potensi ekstrak kulit sakit dan kayu Sengon (Falcataria moluccana) sebagai antimikroba.

\section{Metode Penelitian}

Penelitian ini merupakan penelitian eksperimental yang dilakukan di Laboratorium Mikrobiologi Institut Kesehatan Rajawali. Identifikasi mikroba uji dilakukan dengan pewarnaan Gram. Pembuatan kurva tumbuh bakteri menggunakan spektrofotometer. Mikroba yang diinokulasikan pada medium Nutrient Broth (NB) untuk bakteri dan medium Potato Dextrose Broth (PDB) untuk jamur diambil sebanyak $400 \mu \mathrm{L}$ dan diukur menggunakan spektrofotemeter dengan panjang gelombang $600 \mathrm{~nm}$. Pengukuran diulang setiap 3 jam sampai 48 jam pertumbuhan untuk bakteri, dan jamur diukur setiap 6 jam sampai 150 jam.

Uji aktivitas antimikroba dilakukan dengan melarutkan Ekstrak kulit ranting dan kayu sakit Sengon dengan pelarut metanol dan melarutkan ekstrak kayu sakit Sengon dengan etil asetat. Pembuatan ekstrak yang dipakai menggunakan metode maserasi. Maserasi adalah salah satu metode ekstraksi dengan merendam serbuk simplisia dengan pelarut organik. Metode ini tidak menggunakan panas sehingga senyawa yang tidak tahan panas tidak akan rusak (Amalia et al., 2017). Ekstrak dibuat menjadi lima varian konsentrasi yaitu 9\%, $9,5 \%, 10 \%, 10,5 \%$, dan $11 \%$.

Pengujian ekstrak dilakukan menggunakan metode difusi cakram (Kirby bauer). Antibiotik yang digunakan sebagai kontrol adalah kloramfenikol. Pengujian ekstrak dilakukan dengan cara $20 \mu \mathrm{L}$ kkstrak tersebut diteteskan pada disk kemudian diujikan pada mikroba uji diantaranya Staphylococcus aureus, Pseudomonas aeruginosa, Proteus mirabilis, Salmonella typhi, Shigella dysenteriae, Klebsiella pneumonia, Escerichia coli, dan Candida albicans yang ditumbuhkan pada medium Nutrient Agar (NA) dan diinkubasi selama 24 jam. Hasil yang didapat adalah zona hambat yang terbentuk disekitar disk. Pengukuran zona hambat dilakukan menggunakan penggaris. Hasil dicatat dan di ulangi 2 sampai 3 kali lalu hasilnya dirataratakan dari masing masing mikroba yang diuji.

\section{Hasil Penelitian dan Pembahasan}

Uji aktivitas antimikroba ekstrak kulit ranting dan kayu sakit Sengon (Falcataria moluccana) dengan pelarut metanol dan etil asetat diawali dengan identifikasi mikroba uji. Hasil identifikasi disajikan dalam Tabel 1. Dari hasil identifikasi, untuk bakteri didapatkan dua kelompok bakteri yaitu bakteri Gram positif yang ditandai dengan warna ungu disebabkan kompleks zat warna kristal violet-yodium tetap dipertahankan meskipun diberi larutan alkohol dan bakteri Gram negatif yang ditandai dengan warna merah sebab kompleks tersebut larut pada saat pemberian larutan alkohol dan menyerap zat warna safranin.

Perbedaan penyerapan warna yang terjadi disebabkan karena perbedaan struktur dinding sel pada bakteri Gram positif dan Gram negatif (Nurhidayati et al., 2015). Bakteri Gram positif umumnya memiliki struktur dinding sel yang tebal dengan lapisan peptidoglikan yang lebih banyak sedangkan bakteri Gram negatif memiliki dinding sel yang lebih tipis dan persentase lemak lebih tinggi (Jiwintarum et al., 2016). Hasil identifikasi jamur menggunakan pewarnaan Gram mendapatkan hasil sel ragi benbentuk oval dan berwarna ungu. Hal ini sesuai dengan teori bahwa Candida albicans berbentuk oval (Indrayati et al., 2018). 


\begin{tabular}{|c|c|c|c|c|}
\hline $\begin{array}{c}\text { Jenis } \\
\text { Mikroba }\end{array}$ & $\begin{array}{c}\text { Metode } \\
\text { Identifikasi }\end{array}$ & Bentuk & Warna & Keterangan \\
\hline S.aureus & Pewarnaan Gram & Kokus & Ungu & Gram positif \\
\hline P.aeruginosa & Pewarnaan Gram & Basil & Merah & Gram negatif \\
\hline P.mirabilis & Pewarnaan Gram & Basil & Merah & Gram negatif \\
\hline K.pneumoniae & Pewarnaan Gram & Basil & Merah & Gram negatif \\
\hline S. dysenteriae & Pewarnaan Gram & Basil & Merah & Gram negatif \\
\hline S.typhi & Pewarnaan Gram & Basil & Merah & Gram negatif \\
\hline E.coli & Pewarnaan Gram & Basil & Merah & Gram negatif \\
\hline C.albicans & Pewarnaan Gram & $\begin{array}{c}\text { Sel Ragi } \\
\text { Bentuk Oval }\end{array}$ & Ungu & Gram positif \\
\hline
\end{tabular}

Kurva pertumbuhan mikroba uji baik jamur maupun bakteri menghasilkan bentuk kurva yang beragam. Hasil penelitian menunjukkan fase pertumbuhan dari mikroba uji yang akan dipakai dalam uji aktivitas antimikroba. Kurva pertumbuhan bakteri disajikan pada Gambar 1. Bakteri uji diambil pada jam yang berbeda beda. S.aureus pada jam ke-6, P.aeruginosa pada jam ke-12, P.mirabilis pada jam ke-21, S.typhi pada jam ke-18, S.dysenteriae pada jam ke-15, K.pneumoniae pada jam ke-18, dan terakhir E. coli pada jam ke-15. Pengambilan jamur untuk pengujian aktivitas antimikroba dilakukan pada jam ke-36. Kurva pertumbuhan jamur dapat dilihat pada Gambar 2. Untuk pengujian aktivitas antimikroba, mikroba uji diambil pada fase log karena pada fase tersebut terjadi pembelahan yang cepat sehingga dinding selnya tipis (Sugoro et al., 2008).

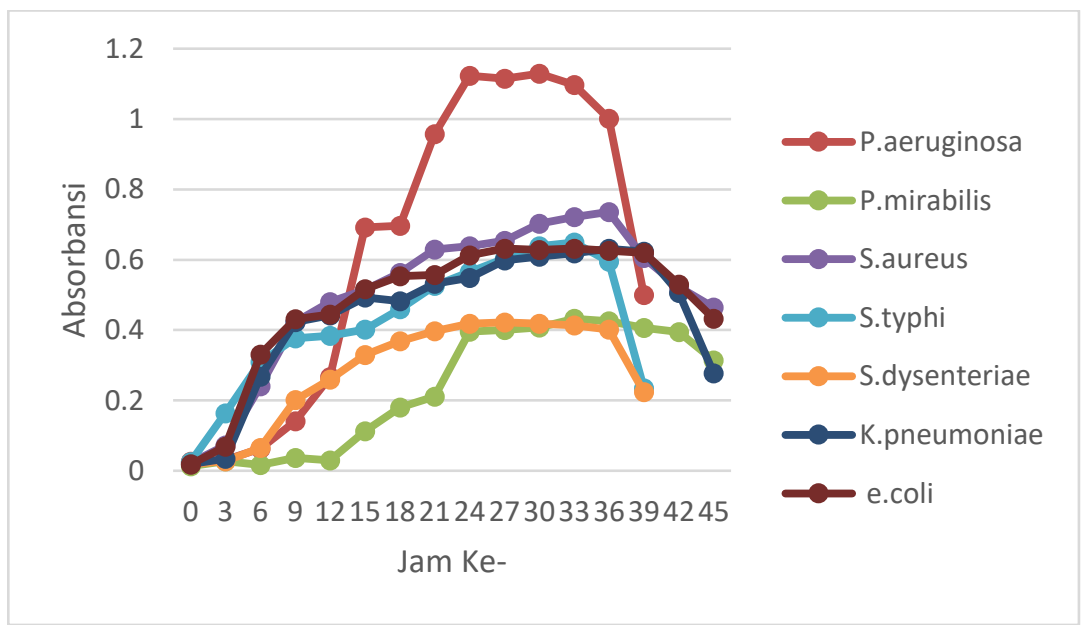

Gambar 1. Kurva Pertumbuhan Bakteri 


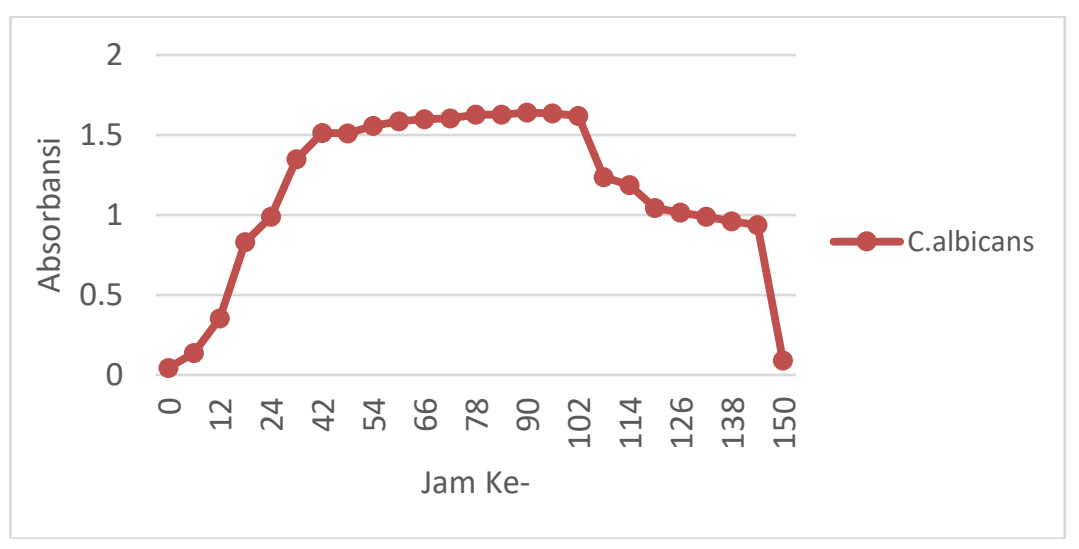

Gambar 2. Kurva Pertumbuhan Jamur

Pengujian aktivitas bakteri ekstrak kulit ranting dan kayu sakit Sengon (Falcataria moluccana) digunakan dua pelarut yaitu metanol dan etil asetat. Kulit ranting sakit dengan pelarut metanol diujikan pada semua mikroba uji, ekstrak kayu sakit dengan pelarut metanol hanya diujikan pada S.aureus, P.aeruginosa, dan P.mirabilis, dan yang terakhir ekstrak kayu sakit etil asetat hanya diujikan pada C.albicans saja. Hasil pengujian aktivitas antimikroba disajikan dalam Tabel 2.

Ekstrak kulit ranting sakit dengan pelarut metanol memperlihatkan hasil zona hambat yang terjadi pada setiaap mikroba uji baik pada semua konsentrasi ataupun hanya beberapa konsentrasi. Zona hambat yang terbentuk semakin bertambah besarnya seiring dengan kenaikan konsentrasi ekstrak yang diujikan. Konsentrasi optimum ekstrak kulit ranting sakit dengan pelarut metanol yaitu $11 \%$ pada $S$. aureus dengan diameter $8,3 \mathrm{~mm}, P$. mirabilis dengan diameter $4,3 \mathrm{~mm}, P$. aeruginosa dengan diameter $0,5 \mathrm{~mm}, K$. pneumonia dengan diameter $9 \mathrm{~mm}$, dan E. coli dengan diameter $7 \mathrm{~mm}$.

Konsentrasi optimum ekstrak kulit ranting sakit dengan pelarut metanol juga terdapat pada konsentrasi $10 \%$ dan $11 \%$ pada $S$. dysenteriae dan C. albicans dengan diameter $3 \mathrm{~mm}$, dan pada $S$. thypi dengan diameter $6 \mathrm{~mm}$. Konsentrasi optimum ekstrak kayu sakit sengon dengan pelarut metanol yaitu $11 \%$ pada $S$. aureus dengan diameter $8,3 \mathrm{~mm}, P$. mirabilis dengan diameter $5,6 \mathrm{~mm}$, dan $P$. aeruginosa dengan diameter $9 \mathrm{~mm}$. Konsentrasi optimum ekstrak kayu sakit sengon dengan pelarut etil asetat yaitu 10\%, 10,5\%, dan $11 \%$ terhadap C. albicans dengan diameter $2 \mathrm{~mm}$. 
Tabel 2. Hasil Uji Aktivitas Antimikroba

\begin{tabular}{|c|c|c|c|c|c|c|c|c|}
\hline \multirow{3}{*}{ Ekstrak } & \multirow{3}{*}{ Pelarut } & \multirow{3}{*}{ Mikroba Uji } & \multicolumn{6}{|c|}{ Zona Hambat (mm) } \\
\hline & & & Kontrol & $9 \%$ & 9,5 & 10 & 10,5 & 11 \\
\hline & & & + & & $\%$ & $\%$ & $\%$ & $\%$ \\
\hline \multirow{9}{*}{$\begin{array}{l}\text { Kulit } \\
\text { Sakit }\end{array}$} & \multirow{9}{*}{ Metanol } & Staphylococcus aureus & 14 & 5,3 & 7 & 7 & 7,7 & 8,7 \\
\hline & & Pseudomonas & 5 & 0 & 0 & 0 & 0 & 0,5 \\
\hline & & aeruginosa & & & & & & \\
\hline & & Proteus mirabilis & 17 & 1,3 & 2,7 & 3 & 3,7 & 4,3 \\
\hline & & Klebsiella pneumoniae & 13,3 & 3 & 6 & 7 & 7,5 & 9 \\
\hline & & Shigella dysenteriae & 16 & 0 & 1 & 3 & 3 & 3 \\
\hline & & Salmonella typhi & 12 & 0 & 4 & 4 & 6 & 6 \\
\hline & & Escherichia coli & 10,3 & 0 & 3 & 4 & 6,5 & 7 \\
\hline & & Candida Albicans & 12 & 0 & 0 & 0 & 3 & 3 \\
\hline \multirow{5}{*}{$\begin{array}{l}\text { Kayu } \\
\text { Sakit }\end{array}$} & \multirow{4}{*}{ Metanol } & Staphylococcus aureus & 14 & 0 & 1 & 1 & 1,3 & 8,3 \\
\hline & & Pseudomonas & 5 & 0 & 1 & 1,3 & 2 & 9 \\
\hline & & aeruginosa & & & & & & \\
\hline & & Proteus mirabilis & 17 & 0 & 0 & 2,3 & 5,3 & 5,6 \\
\hline & Etil Asetat & Candida Albicans & 10,3 & 0 & 1 & 2 & 2 & 2 \\
\hline
\end{tabular}

Dari Tabel 2 terlihat bahwa setiap ekstrak yang diujikan mempunyai kemampuan sebagai antimikroba. Ekstrak kulit ranting dan kayu sakit Sengon memiliki senyawa metabolit sekunder yang beragam. Senyawa flavonoid adalah senyawa yang disintesis oleh tanaman sebagai respon terhadap infeksi mikroba sehingga efektif sebagai zat antibakteri (Haryati et al 2015). Flavonoid merupakan kelompok senyawa fenol terbesar yang ditemukan di alam dan salah satu metabolit sekunder yang terdapat pada tumbuhan. Senyawa ini dapat digunakan sebagai antimikroba, antijamur, antivirus, antikanker, dan antitumor (Mardiana \& Rahayu, 2017) Flavonoid bekerja dengan cara membunuh bakteri secara langsung dan melemahkan patogenesitas bakteri. Selain itu, senyawa flavonoid adalah senyawa aktif yang memiliki efek sebagai antibakteri melalui kemampuan untuk membentuk kompleks dengan protein ekstraseluler dan protein yang dapat larut dengan dinding sel bakteri (Waluyo, 2016).

Alkaloid dapat ditemukan pada berbagai bagian tanaman, seperti bunga, biji, daun, ranting, akar dan kulit batang (Ningrum et al., 2016). Senyawa alkaloid memiliki kemampuan untuk menghambat pertumbuhan bakteri. Kemampuan alkaloid dalam menghambat pertumbuhan bakteri dikaitkan dengan kemampuan mereka berinterkalasi dengan DNA, sehingga menghambat sintesis DNA dan reverse transcriptase, juga dengan melepaskan adhesin asam lipoteikoat dari permukaan sel sehingga mengganggu permeabilitas membran (Mawan et al., 2018). Selain sebagai antibakteri, senyawa alkaloid juga memiliki aktivitas antifungi (Soleman, 2019). Kemampuan tanin sebagai antibakteri dapat dilihat dari aksinya pada membran. Tanin dapat melewati membran sel karena tanin dapat berpresipitasi pada protein. Selain sebagai 
antibakteri tanin juga berperan sebagai antijamur. Mekanisme antijamur yang dimiliki adalah kemampuannya menghambat sistesis khitin untuk pembentukan dinding sel pada jamur dan merusak membran sel sehingga pertumbuhan jamur terhambat (Kurniawati \& Mashartini, 2016)

Senyawa saponin memiliki kemampuan untuk menghambat bakteri. Aktivitas saponin dalam menghambat pertumbuhan bakteri adalah dengan mengurangi efisiensi pemanfaatan glukosa dalam mikroorganisme, mempengaruhi pertumbuhan dan proliferasi, mengurangi aktivitas enzim kunci dalam metabolisme fisiologis dan menekan sintesis protein, kemudian menyebabkan kematian sel (Mawan et al 2018). Pada jamur, saponin Saponin bekerja dengan mengganggu integritas sel C.albicans (Kurniawati \& Mashartini, 2016).

Mekanisme kerja senyawa fenol dalam membunuh sel bakteri, yaitu dengan cara mendenaturasi protein sel bakteri (Marfuah et al 2018). Senyawa fenolik pada konsentrasi rendah dapat merusak membran sitoplasma dan dapat menyebabkan kebocoran inti sel sedangkan pada konsentrasi tinggi senyawa fenol berkoagulasi dengan protein seluler (Haryati et al., 2015). Mekanisme kerja senyawa terpenoid sebagai antibakteri diduga melibatkan kerusakan membran oleh senyawa lipofilik. Steroid sebagai antibakteri adalah dengan cara merusak membran sel bakteri.

Faktor yang dikendalikan dalam penelitian ini adalah konsentrasi ekstrak kulit dan kayu sakit Sengon yang dipakai. Konsentrasi yang dibuat adalah 9\%, 9,5\%, 10\%, 10,5\%, dan 11\%. Kenaikan konsentrasi ini berbanding lurus dengan besarnya zona hambat yang terbentuk karena semakin tinggi konsentrasi, komponen bioaktif yang terdapat di dalam ekstrak semakin banyak sehingga aktivitas antimikroba juga semakin tinggi (Octaviani et al 2019). Penelitian ini juga sangat dipengaruhi oleh beberapa faktor lain. Faktor-faktor yang perlu diperhatikan untuk mendapat kinerja ekstrak yang optimal antara lain adalah asal bahan ekstrak, kondisi iklim, cara penyimpanan bahan ekstrak, perbedaan bahan pengencer, dan kondisi agar. Proses pembuatan ekstrak serta waktu penyimpanan ekstrak yang cukup lama juga bisa menyebabkan terjadinya penurunan aktivitas daya hambat yang dapat ditimbulkan oleh ekstrak tersebut (Wikananda et al., 2019).

\section{Kesimpulan}

Ekstrak kulit ranting dan kayu sakit Sengon (Falcataria Moluccana) dengan pelarut metanol dan etil asetat memiliki aktivitas antimikroba dengan konsentrasi optimum ekstrak kulit ranting sakit dengan pelarut metanol yaitu $11 \%$ pada $S$. aureus, P. mirabilis, P. aeruginosa, K. pneumoniae, dan E. coli, $10 \%$ dan $11 \%$ pada $S$. dysenteriae, S. thypi, dan C. albicans. Konsentrasi optimum ekstrak kayu sakit sengon dengan pelarut metanol yaitu $11 \%$ pada $S$. aureus, $P$. mirabilis, dan $P$. aeruginosa, dan konsentrasi optimum ekstrak kayu sakit sengon dengan pelarut etil asetat terhadap C. albicans yaitu 10\%, 10,5\%, dan $11 \%$. 


\section{Daftar Pustaka}

Amalia, A., Sari, I., \& Nursanty, R. (2017). Aktivitas Antibakteri Ekstrak Etil Asetat Daun Sembung (Blumea balsamifera (L.) Dc.) terhadap Pertumbuhan Bakteri Methicillin Resistant Staphylococcus aereus (MRSA). Prosiding Seminar Nasional Biotik.

Azizah, A., Adnan, M. R., \& Su'udi, M. (2018). POTENSI SERBUK GERGAJI KAYU SENGON SEBAGAI INSEKTISIDA BOTANI. JURNAL BIOSAINS. https://doi.org/10.24114/jbio.v4i2.10518

Fahrizal, M. D. (2014). Total fenolik dan flavonoid serta aktivitas antioksidan ekstrak kulit kayu sengon (Paraserianthes falcataria (L.). Institut Pertanian Bogor.

H., K., E., V., M.H., K., \& M., K. (2011). Paraserianthes falcataria (L.) Nielsen: Ekologi, silvikultur dan produktivitas. In Paraserianthes falcataria (L.) Nielsen: Ekologi, silvikultur dan produktivitas. https://doi.org/10.17528/cifor/003482

Haryati, N., Saleh, C., \& -, E. (2015). Uji Toksisitas Dan Aktivitas Antibakteri Ekstrak Daun Merah Tanaman Pucuk Merah (Syzygium Myrtifolium Walp.) Terhadap Bakteri Staphylococcus Aureus Dan Escherichia Coli. Jurnal Kimia Mulawarman.

Indrayati, S., Suraini, S., \& Afriani, M. (2018). GAMBARAN JAMUR Candida sp. DALAM URINE PENDERITA DIABETES MELLITUS DI RSUD dr. RASIDIN PADANG. JURNAL KESEHATAN PERINTIS (Perintis's Health Journal). https://doi.org/10.33653/jkp.v5i1.93

Jiwintarum, Y., Rohmi, \& Prayuda, I. D. P. M. (2016). BUAH NAGA (Hylocereus Polyrhizus) SEBAGAI PEWARNA ALAMI UNTUK PEWARNAAN BAKTERI Yunan. Jurnal Kesehatan Prima.

Kurniawati, A., \& Mashartini, A. (2016). Perbedaan khasiat anti jamur antara ekstrak etanol daun Kersen (Muntingia calabura L .) dengan nistatin terhadap pertumbuhan Candida albicans. Jurnal PDGI.

Mardiana, \& Rahayu, I. G. (2017). Pengantar Laboratorium Medik. In Bahan Ajar Teknologi Laboratorium Medis (TLM).

Mawan, A. R., Indriwati, S. E., \& Suhadi, S. (2018). AKTIVITAS ANTIBAKTERI EKSTRAK METANOL BUAH Syzygium polyanthum TERHADAP PERTUMBUHAN BAKTERI Escherichia coli. Bioeksperimen: Jurnal Penelitian Biologi. https://doi.org/10.23917/bioeksperimen.v4i1.5934

Ningrum, R., Purwanti, E., \& Sukarsono. (2016). Identifikasi Senyawa Alkaloid dari Batang Karamunting (Rhodomyrtus tomentosa) Sebagai Bahan Ajar Biologi Untuk SMA Kelas X. Jurnal Pendidikan Biologi Indinesia.

Nurhidayati, S., Faturrahman, F., \& Ghazali, M. (2015). DETEKSI BAKTERI PATOGEN YANG BERASOSIASI DENGAN Kappaphycus alvarezii (Doty) BERGEJALA PENYAKIT ICE-ICE. Jurnal Sains Teknologi \& Lingkungan. https://doi.org/10.29303/jstl.v1i2.53

Pratiwi, P., Winarsa, R., \& Purwaringingsih. (2019). Toksisitas Ekstrak Ekstraksi Serbuk Gergaji Kayu Sengon Laut (Albizia falcataria L. Forberg) Terhadap Mortalitas Hypothenemus hampei Ferr. Jurnal Pro-Life.

Soleman, D. (2019). Aktivitas Antifungi Ekstrak Metanol Kulit Batang Jambu Mete (Anacardium occidentale L.) Terhadap Candida albicans Dengan Metode Difusi Sumuran Antifungal. Akademi Farmasi Putra Indonesia Malang. 
Sugoro, I., Windusari, Y., \& Tetriana, D. (2008). DOSIS INAKTIF DAN KADAR PROTEIN Klebsiella pneumonia K5 HASIL IRADIASI GAMMA. A Scientific Journal for The Applications of Isotopes and Radiation.

Waluyo, J. (2016). Aya Hambat Ekstrak Etanol Daun Akasia Berduri(Acacia Nilotica L.) Terhadap Pertumbuhan Bakteri Streptococcus Pneumoniae. Jurnal Pembelajaran Fisika Universitas Jember.

Wikananda, I. D. A. R. N., Hendrayana, M. A., \& Pinatih, K. J. P. (2019). EFEK ANTIBAKTERI EKSTRAK ETHANOL KULIT BATANG TANAMAN CEMPAKA KUNING (M. champaca L.) TERHADAP PERTUMBUHAN Staphylococcus aureus. Jurnal Medika.

Wiryadana, K. A., Pinatih, K. J. P., \& Hendrayana, M. A. (2019). Uji Daya Hambat Kombinasi Siprofloksasin dengan Obat Non-antibiotik Artesunat, Diklofenak dan Loperamid Terhadap Pertumbuhan Isolat Klinis Escherichia Coli. E-Jurnal Medika Udayana. 